\title{
Serum levels of insulin-like factor 3, anti-Müllerian hormone, inhibin B, and testosterone during pubertal transition in healthy boys: a longitudinal pilot study
}

\author{
Marie Lindhardt Johansen*, Ravinder Anand-Ivell ${ }^{1, *}$, Annette Mouritsen, Casper P Hagen, \\ Mikkel G Mieritz, Tue Søeborg, Trine Holm Johannsen, Katharina M Main, Anna-Maria Andersson, \\ Richard Ivell ${ }^{2}$ and Anders Juul \\ Department of Growth and Reproduction, GR 5064, Rigshospitalet, University of Copenhagen, Blegdamsvej 9, \\ DK-2100 Copenhagen Ø, Denmark, ${ }^{1}$ School of Bioscience, University of Nottingham, Nottingham, UK and \\ ${ }^{2}$ Leibniz Institute for Farm Animal Biology, 18196 Dummerstorf, Germany
}

Correspondence should be addressed to A Juul; Email: anders.juul@regionh.dk

*(M L Johansen and R Anand-Ivell contributed equally to this work)

\begin{abstract}
Insulin-like factor 3 (INSL3) is a promising marker of Leydig cell function with potentially high clinical relevance. Limited data of INSL3 levels in relation to other reproductive hormones in healthy pubertal boys exist. In this study, we aimed to evaluate longitudinal serum changes in INSL3 compared with LH, FSH, testosterone, inhibin B, and anti-Müllerian hormone (AMH) during puberty in healthy boys. Ten boys were included from the longitudinal part of the COPENHAGEN Puberty Study. Pubertal evaluation, including testicular volume, was performed and blood samples were drawn every 6 months for 5 years. Serum concentrations of testosterone were determined by a newly developed LC-MS/MS method, and serum concentrations of INSL3, AMH, inhibin B, FSH, and LH respectively were determined by validated immunoassays. The results showed that serum INSL3 levels increased progressively with increasing age, pubertal onset, and testicular volume. In six of the ten boys, LH increased before the first observed increase in INSL3. In the remaining four boys, the increase in LH and INSL3 was observed at the same examination. The increases in serum concentrations of LH, testosterone, and INSL3 were not parallel or in ordered succession and varied interindividually. We demonstrated that INSL3 concentrations were tightly associated with pubertal onset and increasing testicular volume. However, the pubertal increases in LH, INSL3, and testosterone concentrations were not entirely parallel, suggesting that INSL3 and testosterone may be regulated differently. Thus, we speculate that INSL3 provides additional information on Leydig cell differentiation and function during puberty compared with traditional markers of testicular function.

Reproduction (2014) 147 529-535
\end{abstract}

\section{Introduction}

Insulin-like factor 3 (INSL3) is a peptide hormone secreted by Leydig cells in the testis and by theca cells

\footnotetext{
This paper forms part of a special issue of Reproduction on Endocrine Disrupters. This article was presented at the 7th Copenhagen Workshop on Endocrine Disrupters, 28-31 May 2013. The meeting was supported by the Danish Ministry of the Environment - Environmental Protection Agency as an activity under the Danish Centre on Endocrine Disrupters. Publication of this special issue has been supported by the Society for Reproduction and Fertility. The opinions or views expressed in this special issue are those of the authors, and do not necessarily reflect the opinions or recommendations of the Danish Ministry of the Environment - Environmental Protection Agency or the Society for Reproduction and Fertility. The Guest Editors for this special issue were Anna-Maria Andersson, Hanne Frederiksen, Niels Erik Skakkebæk, Rigshospitalet, Denmark, Kenneth M Grigor, Western General Hospital, Edinburgh, UK and Jorma Toppari, University of Turku, Finland
}

in the ovary. INSL3 exerts its effect through the G-protein-coupled relaxin family peptide receptor 2 (RXFP2) (Huang et al. 2012), which in transfected cell systems activates the stimulatory G-protein leading to an increase in cAMP (Kumagai et al. 2002, Heng et al. 2008). In rodent gametes, RXFP2 may also couple to the inhibitory G-protein (Kawamura et al. 2004, Hutson 2013). The expression of INSL3 is believed to be regulated by luteinizing hormone ( $\mathrm{LH}$; Foresta et al. 2004, Bay et al. 2006, Ferlin et al. 2006a, Cabrol et al. 2011, Roth et al. 2013) in a chronic, cell differentiationrelated manner rather than the acute regulation that $\mathrm{LH}$ exerts on testosterone (Bay et al. 2005, Anand-Ivell et al. 2006a, Bay \& Andersson 2011). Both gene expression and protein secretion studies in rodents show that INSL3 reflects a relatively mature Leydig cell phenotype (Ivell et al. 2013). 
INSL3 is, along with testosterone, responsible for the hormonal control of the descent of the testes in the male fetus (for reviews see Bay et al. (2011) and Hutson (2013)). The trans-abdominal phase of testicular descent is completely dependent on INSL3 due to its trophic effect on the gubernaculum (Zimmermann et al. 1999, Kubota et al. 2002). This hypertrophy of the ligament along with the growth of the fetus causes the testes to be placed at the superior end of the future inguinal canals. Functional mutations of either the INSL3 or the RXFP2 gene causes cryptorchidism in rodents as well as in humans (Nef \& Parada 1999, Zimmermann et al. 1999, Tomboc et al. 2000, Ferlin et al. 2003, 2006b, Foresta \& Ferlin 2004). The later phase(s) of testicular descent are driven by androgens, although the exact mechanisms are unknown (Hutson 2013).

The physiological role of INSL3 in adult life remains unclear. A role in the maintenance of spermatogenesis by ensuring germ cell survival has, however, been proposed (Kawamura et al. 2004), although studies using conditional knockout mice suggest that this is not an essential function (Huang et al. 2012). Non-gonadal roles of INSL3 are suggested by the presence of RXFP2 receptors in many tissues other than testis, including epididymis (Anand-Ivell et al. 2006b), brain, bone marrow, muscle, kidney, thyroid, and peripheral blood cells (Hsu et al. 2002).

Several studies have described serum levels of INSL3 from fetal life to adulthood in humans. In two human studies, INSL3 was detectable in second-trimester amniotic fluid (at the time of the trans-abdominal phase of testicular descent) of male fetuses (Anand-Ivell et al. 2008, Bay et al. 2008), whereas INSL3 was undetectable in the amniotic fluid of female fetuses (Bay et al. 2008). Serum concentrations of INSL3 increase during the postnatal activation of the pituitary-gonadal axis at around 2-3 months of age (a process termed mini-puberty) in healthy boys (Bay et al. 2007), as well as in boys with Klinefelter syndrome (Cabrol et al. 2011). In healthy adult men, INSL3 levels appear to be relatively stable (Foresta et al. 2004, Bay et al. 2005) until they decline from aged mid-thirties onwards, probably reflecting a decline in Leydig cell functional capacity (Anand-Ivell et al. 2006a). In adults with Klinefelter syndrome, INSL3 levels are low (Foresta et al. 2004, Bay et al. 2005). Furthermore, serum concentrations of INSL3 do not appear to respond acutely to gonadotropin stimulation in reproductively healthy men once a certain baseline level has been reached (Bay et al. 2005, 2006).

To our knowledge, serum concentrations of INSL3 throughout puberty have been investigated in only two previous studies: one cross-sectional study of 75 healthy boys aged 9-17 years (Ferlin et al. 2006a) and one longitudinal study of 14 boys with idiopathic short stature (Wikstrom et al. 2006). To further elucidate INSL3 levels throughout pubertal transition, we present unique longitudinal data from a pilot study on serum INSL3 concentrations in ten healthy boys before and during puberty in comparison with other reproductive hormones.

\section{Materials and methods}

\section{Subjects}

This is a secondary analysis of the longitudinal part of the COPENHAGEN Puberty Study (Aksglaede et al. 2009, Sorensen et al. 2010, Hagen et al. 2012, Mouritsen et al. 2013), which includes a total of 208 children. Ten boys were selected from the 208 participants based on three criteria: i) Caucasian origin, ii) having at least seven clinical examinations (simultaneous blood sampling was not a prerequisite), three before and four after the onset of puberty, and iii) male gender. Blood sampling and pubertal staging were carried out every 6 months between 2006 and 2011. The researcher selecting the ten boys was blinded to all hormone values. Part of the data (regarding $\mathrm{LH}$, anti-Müllerian Hormone $(\mathrm{AMH})$, and testosterone) has previously been published (Aksglaede et al. 2010, Mouritsen et al. 2013, 2014).

\section{Clinical examination}

Testicular volume was determined by Prader's orchidometer to the nearest milliliter (Prader 1966). Both right and left testicular volumes were recorded, and the larger volume was used as the determinant. Pubertal onset was defined as testicular volume $>3 \mathrm{ml}$ at all subsequent examinations. Pubertal staging was according to Tanner (G1-G5).

\section{Statistical analyses}

Changes in INSL3 concentrations between one examination before and one following pubertal onset were evaluated using Wilcoxon's signed-rank test.

\section{Hormone assays}

Blood was drawn from an antecubital vein in the morning between 0800 and $1000 \mathrm{~h}$. Immediately after blood sampling, the samples were centrifuged and aliquoted into cryotubes, which were stored at $-20^{\circ} \mathrm{C}$ until hormone analyses were performed. We analyzed all blood samples for all reproductive hormones, bar INSL3, in the same laboratory blinded for the technician for pubertal staging. Serum concentrations of follicle-stimulating hormone (FSH) and $\mathrm{LH}$ were determined using the time-resolved immunofluorometric assays (Delfia; PerkinElmer, Boston, MA, USA). The limits of detection (LODs) were 0.06 and $0.05 \mathrm{IU} / \mathrm{I}$ respectively with intra- and inter-assay coefficients of variation $(\mathrm{CV})$ of $<5 \%$ respectively in both assays. Serum concentrations of inhibin B were measured using the Beckman Coulter Genll assay with an LOD of $3 \mathrm{pg} / \mathrm{ml}$, and inter-assay CV were $<11 \%$. Serum concentrations of $\mathrm{AMH}$ were measured using the Immunotech Beckman Coulter enzyme immunometric assay with an LOD of $2 \mathrm{pmol} / \mathrm{l}$, and inter-assay CV were $<14 \%$. The AMH samples were diluted $(1: 10)$ if the boy was below the age of 13 years. If the concentration in a boy older than 13 was above $150 \mathrm{pmol} / \mathrm{l}$, 
the sample was diluted and then reanalyzed: 54 of 93 samples were diluted in this study. Serum concentrations of testosterone were quantified using an in-house TurboFlow-LC-MS/MS method as previously described (Soeborg et al. 2013), and serum concentrations of INSL3 were measured using a wellestablished TRFIA (Anand-Ivell et al. 2006a), recently modified for higher sensitivity (Anand-Ivell et al. 2013). The LOD was $10 \mathrm{pg} / \mathrm{ml}$, with intra- and inter-assay CV across the range of measurement of $<3$ and $<10 \%$ respectively.

\section{Ethical considerations}

The Copenhagen Puberty Study (ClinicalTrials.gov ID: NCT01411527) was approved by the Local Ethics Committee (numbers KF 01282214 and V200.1996/90) and the Danish Data Protection Agency (2010-41-5042). All participants and parents gave informed consent.

\section{Results}

Serum concentrations of INSL3 increased with age with large interindividual variability (Fig. 1A) and with pubertal onset (Fig. 1B). The increase in INSL3 concentrations between one examination before and one following pubertal onset was significant $(P=0.009)$. Furthermore, INSL3 concentrations increased with genital stages (median INSL3 (ng/ml) (range)): G1 (0.145 (0.036-0.272)), G2 (0.375 (0.118-0.693)), G3 (0.844 (0.367-1.370)), G4 (1.080 (0.896-2.135)), and G5 (1.579 (0.999-1.905)). Testicular volume appeared to increase with both age and puberty (Fig. 1C and D).

Figure 2A, B, C, D, E, F, G, H, I and J illustrates the longitudinal hormone concentrations (INSL3, LH, testosterone, $\mathrm{AMH}$, inhibin $\mathrm{B}$, and $\mathrm{FSH}$ ) along with testicular volumes for each individual boy. In six of the ten boys (Fig. 2A, D, E, G, I and J), serum concentrations of $\mathrm{LH}$ were the first to increase, at around the time of pubertal onset, followed by an increase in INSL3 concentrations observed at the next examination. In the remaining four boys (Fig. 2B, C, F and $\mathrm{H}$ ), the increase in $\mathrm{LH}$ and INSL3 was observed at the same examination. The increases in serum concentrations of LH, testosterone, and INSL3 was not parallel or in ordered succession and varied interindividually (Fig. 2). All the boys showed a decrease in $\mathrm{AMH}$ and increase in inhibin B and FSH following puberty.

Most of the boys went through pubertal transition with hormonal onset (increasing $\mathrm{LH}$ and in some cases also testosterone and/or INSL3 concentrations) before clinical pubertal onset. Boy I appeared to progress through puberty slowly, with a clinical onset occurring before significant increases in reproductive hormones. Furthermore, we also noted an intra-individual variability, with testicular volumes decreasing between some clinical examinations (boys A, B, C, D, G and H).

\section{Discussion}

This pilot study presents longitudinal measurements of serum INSL3, LH, FSH, testosterone, inhibin B, and $\mathrm{AMH}$ in ten healthy boys before and during pubertal transition. Our data provide unique details on the associations between gonadotropins and Leydig and Sertoli cell markers in each boy. Our study suggests that INSL3 may provide additional information on Leydig cell function in pubertal boys compared with the information provided by the measurement of serum testosterone alone.

The purpose of this small pilot study was to look at the intra-individual progress of the reproductive hormones and their interrelationship longitudinally during puberty.
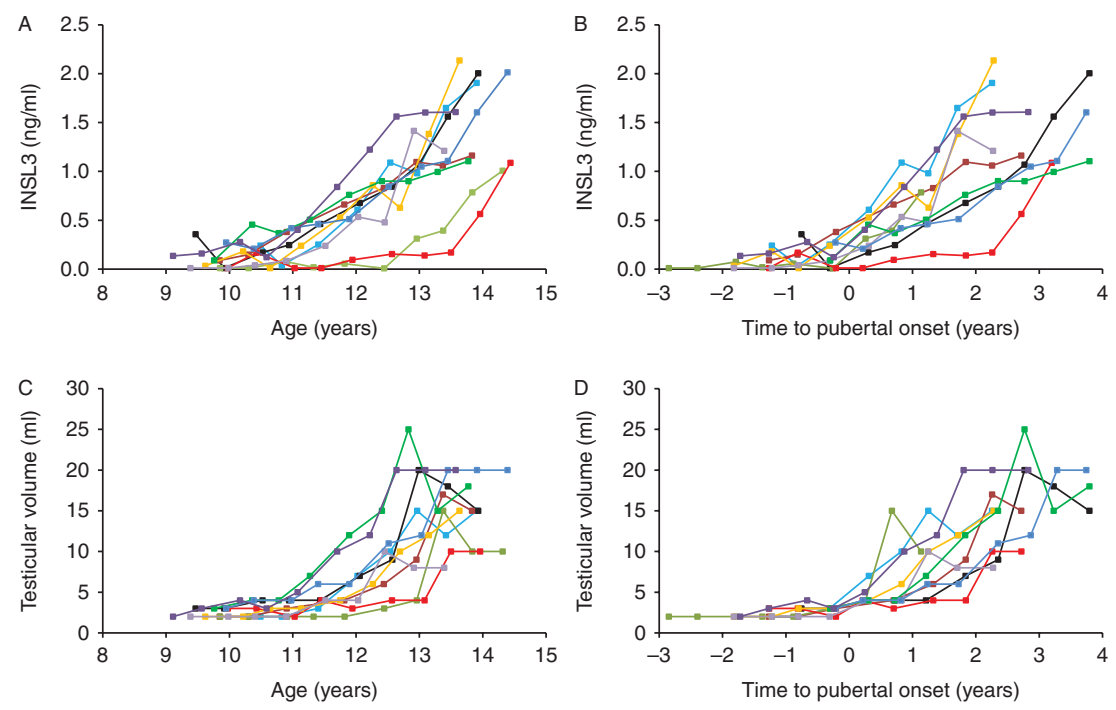

$$
\begin{aligned}
& \rightarrow A \rightarrow B \rightarrow C \rightarrow D \rightarrow E \\
& \rightarrow F \rightarrow G \rightarrow H \rightarrow I \rightarrow J
\end{aligned}
$$

Figure 1 Serum concentrations of insulin-like factor 3 (INSL3) according to age (A) and time to pubertal onset (B). Testicular volume according to age $(\mathrm{C})$ and time to pubertal onset (D) (defined as testicular volume above $3 \mathrm{ml}$ ). Each color and corresponding letter (A, B, C, D, E, F, G, H, I and J) represents the same boy in (A), (B), (C) and (D). 

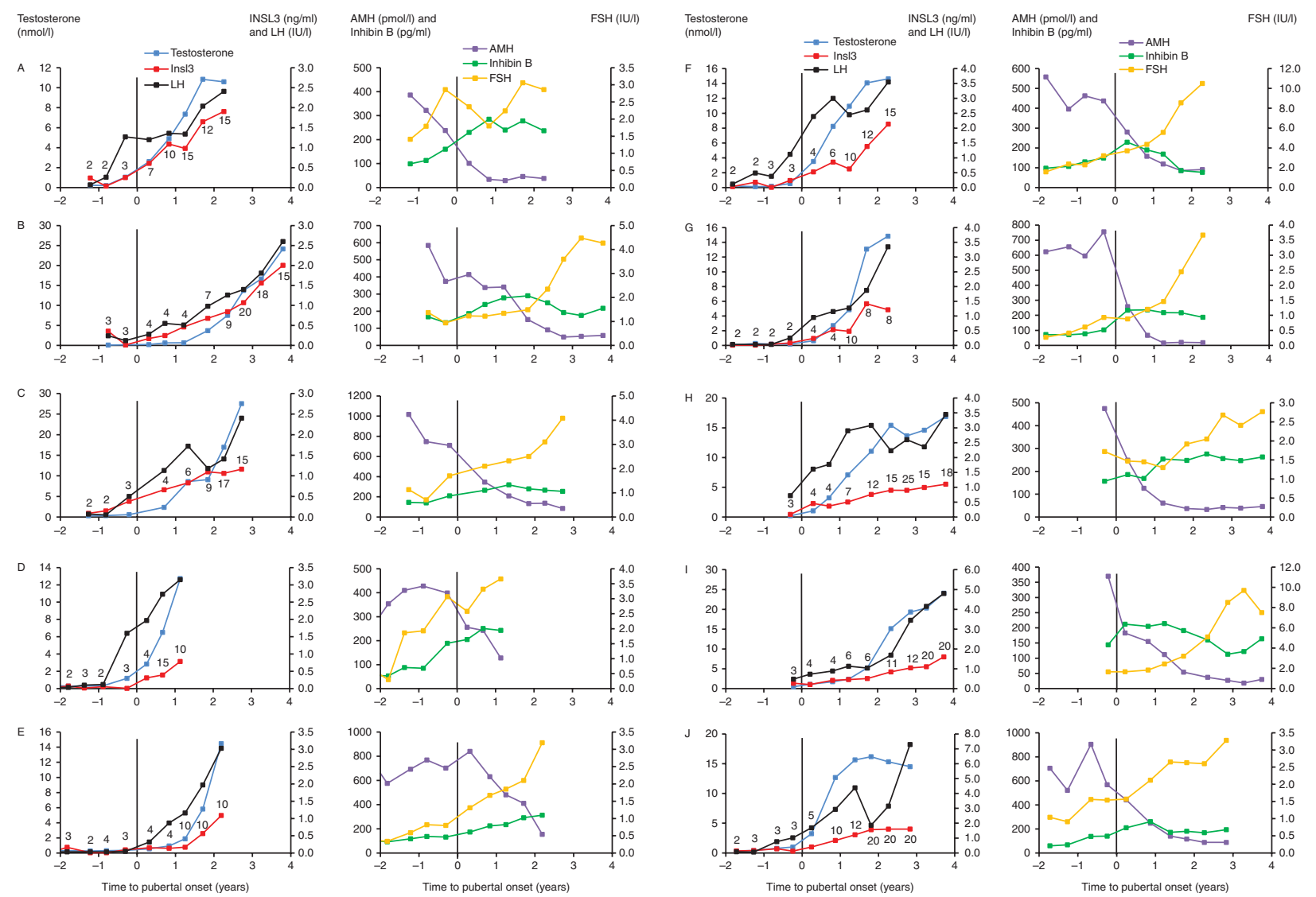

Figure 2 Reproductive hormones according to pubertal onset. Each horizontal pair of graphs represents one boy. Left column represents the pituitary-Leydig cell axis (luteinizing hormone (LH), testosterone, and insulin-like factor 3 (INSL3)); right column represents the pituitary-Sertoli cell axis (follicle-stimulating hormone (FSH), inhibin B, and anti-Müllerian hormone (AMH)). Numbers along the INSL3 curves represent individual testicular volumes $(\mathrm{ml})$ at the clinical examination. Letters $(\mathrm{A}, \mathrm{B}, \mathrm{C}, \mathrm{D}, \mathrm{E}, \mathrm{F}, \mathrm{G}, \mathrm{H}, \mathrm{I}$ and $\mathrm{J}$ ) correspond to letters (and thus the same boy) in Fig. 1.

Thus a major limitation of this study is its small size, which does not allow conclusions to be drawn about interindividual hormone levels, i.e. our data are not as suitable as a general population-based reference.

Our data provide novel and detailed information on the increases in serum concentrations of $\mathrm{LH}$, testosterone, and INSL3 seen throughout puberty in ten healthy boys. There was no discernible pattern in the succession of increase in gonadotropins vs sex steroids and INSL3 around pubertal onset. This is slightly contradictory to cross-sectional data previously published, which suggested that the pubertal increase in INSL3 anticipates the increase in testosterone (Ferlin et al. 2006a). Differences in study design, i.e. cross-sectional vs longitudinal, may explain this divergence, as individual 'increases' cannot be deducted from such crosssectional studies, but require a longitudinal design as in our present study. Furthermore, we found that in all boys, serum concentrations of $\mathrm{LH}$ increased either before or at the same examination, as does INSL3. As blood sampling was performed every 6 months, we may in some cases have missed the LH surge. Our findings are indicative of INSL3 being chronically regulated by LH throughout childhood and adolescence, which supports the conclusions of previous studies. Several studies have found positive correlations, some significant, between LH and INSL3 concentrations (Foresta et al. 2004, Bay et al. 2005, Ferlin et al. 2006a, Cabrol et al. 2011). Furthermore, INSL3 concentrations in serum increase upon long-term stimulation (weeks or months) with human chorionic gonadotropin in gonadotropin-suppressed men, and decrease in response to gonadotropin suppression, further supporting the chronic regulation of INSL3 by LH (Bay et al. 2006, Roth et al. 2013).

The fact that the pubertal increases in INSL3 and testosterone seen in this study were non-parallel could indicate that although both hormones may be regulated by $\mathrm{LH}$, the regulation may differ. It is believed that $\mathrm{LH}$ has a non-acute, long-term effect on Leydig cells, promoting their differentiation to a more mature phenotype (Ivell et al. 2013), and thus a chronic effect on the production of INSL3, as opposed to the acute regulation of testosterone (Bay et al. 2005). Together with the observed constitutive expression in cultured Leydig cells (Sadeghian et al. 2005), and the high within-individual consistency $(<10 \%$ variation) of INSL3 measurements 
in men over periods of several months ( $R$ Anand-Ivell and R Ivell, unpublished data), this implies that INSL3 is not subjected to the acute variations known for testosterone (Ivell \& Anand-Ivell 2009, Bay et al. 2011). If that is the case, it is unlike testosterone (and inhibin B), for which substantial diurnal patterns have been described (Resko \& Eik-nes 1966, Veldhuis et al. 1987, Carlsen et al. 1999, Ankarberg-Lindgren \& Norjavaara 2004). Thus, INSL3 may be a valuable supplement to testosterone as a biomarker of Leydig cell function. The value of serum INSL3 is especially obvious in the case of pubertal induction with mild androgen supplementation in a boy with delayed puberty, as a serum testosterone measurement would not distinguish between endogenous and exogenous testosterone.

The increase in INSL3 concentrations seen between 3 months before and 3 months following clinical pubertal onset was significant. We furthermore observed an increase in INSL3 concentrations between all genital stages from G1 to G5. These findings could signify that measurements of serum INSL3 can be used as a predictor of puberty onset and progression, although the limited size of our study needs to be kept in mind. Significant increases in serum levels of $\mathrm{LH}$, testosterone, and INSL3 between Tanner stages G1 and G2 have also been reported in a former study (Wikstrom et al. 2006). Previously, early morning testosterone has been shown to be a fairly accurate predictor of imminent puberty (Wu et al. 1993). Another study suggested that significant increases in the concentrations of LH in morning urine occur 1-2 years before clinical onset of puberty (Demir et al. 1996). A recent study found that urinary concentrations of $\mathrm{LH}$ and $\mathrm{FSH}$ at the age of 9 were able to predict Tanner stages at the age of 12 (Koenis et al. 2013). A study similar to these focusing on the applicability of INSL3 as a forecaster is, however, necessary to investigate the potential significance of INSL3.

While this pilot study provides detailed information on the pituitary-Leydig cell axis and on Leydig cell maturation, we also present similar, detailed information on the pituitary-Sertoli cell axis $(\mathrm{FSH}$, inhibin $\mathrm{B}$, and $\mathrm{AMH}$ ) and Sertoli cell maturation. We observed the expected increase in $\mathrm{FSH}$ concentrations, followed by a decrease in the serum concentration of $\mathrm{AMH}$ and an increase in the serum concentration of inhibin $B$ around the onset of clinical puberty, as previously published (Aksglaede et al. 2010). This underlines that the ten boys in fact are healthy and seem to progress through puberty as expected.

To determine testicular volume and thereby clinical pubertal onset in this study, Prader's orchidometer was used. Intra-individual variability in testicular volumes was observed. Boy I, for example, seemed to progress through puberty slowly, which may be explained by an inaccuracy in the assessment of testicular volumes. The boy may in fact have had his pubertal onset at the time of pituitary-gonadal activation, as would be expected.
Although an actual decrease in testicular volume between examinations cannot be ruled out, it is more likely that the observed variability is due to observer variations when using the orchidometer. The inaccuracy of Prader's orchidometer is well described in the literature, although varying degrees of inter- and intraobserver biases have been found (Rivkees et al. 1987, Behre et al. 1989, Tatsunami et al. 2006), and some authors did not find large variations (Karaman et al. 2005). Ultrasonography is reported as a far more accurate and reproducible way of measuring testicular volume (Rivkees et al. 1987, Behre et al. 1989, Sakamoto et al. 2007, Lin et al. 2009), but is limited by its impracticality. Our study took place at two schools rendering it difficult and impractical to determine testicular volumes by ultrasound.

In conclusion, this small but unique study showed longitudinal data on serum concentrations of INSL3, LH, $\mathrm{FSH}, \mathrm{AMH}$, testosterone, and inhibin $\mathrm{B}$ during pubertal transition in ten healthy boys. INSL3 levels were tightly and significantly linked to pubertal onset, the LH surge, and also to increasing testicular volume. The increase in serum concentrations of LH, INSL3, and testosterone during pubertal transition was not parallel, thus suggesting different regulating mechanisms and indicating a potential clinical value of INSL3 as a biomarker of Leydig cell function.

\section{Declaration of interest}

The authors declare that there is no conflict of interest that could be perceived as prejudicing the impartiality of the research reported.

\section{Funding}

The Danish Research council (DFF - 1331-00113), the Capital Region Research Fund (R129-A3966), the Kristen and Freddy Johansen Foundation, and The Research Fund of Rigshospitalet, Copenhagen University Hospital. This article is based on work presented at the 7th Copenhagen Workshop on Endocrine Disrupters, which was supported by the Danish Ministry of the Environment - Environmental Protection Agency. Publication of this special issue was supported by the Society for Reproduction and Fertility. The authors $(M L$ Johansen, K M Main, T Søeborg, C P Hagen, A Mouritsen, T H Johannsen, M G Mieritz, and A Juul) are employed at the Department of Growth and Reproduction, where the national center for endocrine disruptors $(\mathrm{CeHoS})$ that is financed by the Danish Ministry of the Environment is located. T Søeborg, A Juul, and A M Andersson have all been involved in projects run under and financed by the Centre on Endocrine Disrupters. The authors A M Andersson and A Juul are members of the CeHoS steering group, and A M Andersson is the leader of CeHoS. The authors A M Andersson, A Juul, and $\mathrm{R}$ Ivell gave oral presentations including the scientific data in the present publication at the COW meeting, and $\mathrm{R}$ Ivell was reimbursed for travel and accommodation. 


\section{Acknowledgements}

The authors gratefully acknowledge the expert technical help of Ms Caterina Pöppel, Dummerstorf, Rostock, MecklenburgVorpommern, Germany.

\section{References}

Aksglaede L, Sorensen K, Petersen JH, Skakkebaek NE \& Juul A 2009 Recent decline in age at breast development: the Copenhagen Puberty Study. Pediatrics 123 e932-e939. (doi:10.1542/peds.2008-2491)

Aksglaede $L$, Sorensen $K$, Boas $M$, Mouritsen A, Hagen CP, Jensen RB, Petersen JH, Linneberg A, Andersson AM, Main KM et al. 2010 Changes in anti-Mullerian hormone (AMH) throughout the life span: a populationbased study of 1027 healthy males from birth (cord blood) to the age of 69 years. Journal of Clinical Endocrinology and Metabolism 95 5357-5364. (doi:10.1210/jc.2010-1207)

Anand-Ivell R, Wohlgemuth J, Haren MT, Hope PJ, Hatzinikolas G, Wittert G \& Ivell R 2006a Peripheral INSL3 concentrations decline with age in a large population of Australian men. International Journal of Andrology 29 618-626. (doi:10.1111/j.1365-2605.2006.00714.x)

Anand-Ivell RJ, Relan V, Balvers M, Coiffec-Dorval I, Fritsch $M$, Bathgate RA \& Ivell R 2006b Expression of the insulin-like peptide 3 (INSL3) hormone-receptor (LGR8) system in the testis. Biology of Reproduction 74 945-953. (doi:10.1095/biolreprod.105.048165)

Anand-Ivell R, Ivell R, Driscoll D \& Manson J 2008 Insulin-like factor 3 levels in amniotic fluid of human male fetuses. Human Reproduction $\mathbf{2 3}$ 1180-1186. (doi:10.1093/humrep/den038)

Anand-Ivell R, Tremellen K, Dai Y, Heng K, Yoshida M, Knight P, Hale G \& Ivell R 2013 Circulating insulin-like factor 3 (INSL3) in healthy and infertile women. Human Reproduction 28 3093-3102. (doi:10.1093/humrep/det349)

Ankarberg-Lindgren C \& Norjavaara E 2004 Changes of diurnal rhythm and levels of total and free testosterone secretion from pre to late puberty in boys: testis size of $3 \mathrm{ml}$ is a transition stage to puberty. European Journal of Endocrinology 151 747-757. (doi:10.1530/eje.0.1510747)

Bay K \& Andersson AM 2011 Human testicular insulin-like factor 3: in relation to development, reproductive hormones and andrological disorders. International Journal of Andrology 34 97-109. (doi:10.1111/ j.1365-2605.2010.01074.x)

Bay K, Hartung S, Ivell R, Schumacher $M$, Jurgensen D, Jorgensen $N$, Holm M, Skakkebaek NE \& Andersson AM 2005 Insulin-like factor 3 serum levels in 135 normal men and 85 men with testicular disorders: relationship to the luteinizing hormone-testosterone axis. Journal of Clinical Endocrinology and Metabolism 90 3410-3418. (doi:10.1210/ jc.2004-2257)

Bay K, Matthiesson KL, McLachlan RI \& Andersson AM 2006 The effects of gonadotropin suppression and selective replacement on insulin-like factor 3 secretion in normal adult men. Journal of Clinical Endocrinology and Metabolism 91 1108-1111. (doi:10.1210/jc.2005-1865)

Bay K, Virtanen HE, Hartung S, Ivell R, Main KM, Skakkebaek NE, Andersson AM \& Toppari J 2007 Insulin-like factor 3 levels in cord blood and serum from children: effects of age, postnatal hypothalamic-pituitarygonadal axis activation, and cryptorchidism. Journal of Clinical Endocrinology and Metabolism 92 4020-4027. (doi:10.1210/jc.2007-0974)

Bay K, Cohen AS, Jorgensen FS, Jorgensen C, Lind AM, Skakkebaek NE \& Andersson AM 2008 Insulin-like factor 3 levels in second-trimester amniotic fluid. Journal of Clinical Endocrinology and Metabolism 93 4048-4051. (doi:10.1210/jc.2008-0358)

Bay K, Main KM, Toppari J \& Skakkebaek NE 2011 Testicular descent: INSL3, testosterone, genes and the intrauterine milieu. Nature Reviews. Urology 8 187-196. (doi:10.1038/nrurol.2011.23)

Behre HM, Nashan D \& Nieschlag E 1989 Objective measurement of testicular volume by ultrasonography: evaluation of the technique and comparison with orchidometer estimates. International Journal of Andrology 12 395-403. (doi:10.1111/j.1365-2605.1989.tb01328.x)

Cabrol S, Ross JL, Fennoy I, Bouvattier C, Roger M \& Lahlou N 2011 Assessment of Leydig and Sertoli cell functions in infants with nonmosaic Klinefelter syndrome: insulin-like peptide 3 levels are normal and positively correlated with LH levels. Journal of Clinical Endocrinology and Metabolism 96 E746-E753. (doi:10.1210/jc.20102103)

Carlsen E, Olsson C, Petersen JH, Andersson AM \& Skakkebaek NE 1999 Diurnal rhythm in serum levels of inhibin B in normal men: relation to testicular steroids and gonadotropins. Journal of Clinical Endocrinology and Metabolism 84 1664-1669. (doi:10.1210/jcem.84.5.5708)

Demir A, Voutilainen R, Juul A, Dunkel L, Alfthan H, Skakkebaek NE \& Stenman UH 1996 Increase in first morning voided urinary luteinizing hormone levels precedes the physical onset of puberty. Journal of Clinical Endocrinology and Metabolism 81 2963-2967. (doi:10.1210/ jcem.81.8.8768859)

Ferlin A, Simonato M, Bartoloni L, Rizzo G, Bettella A, Dottorini T, Dallapiccola B \& Foresta C 2003 The INSL3-LGR8/GREAT ligandreceptor pair in human cryptorchidism. Journal of Clinical Endocrinology and Metabolism 88 4273-4279. (doi:10.1210/jc.2003-030359)

Ferlin A, Garolla A, Rigon F, Rasi CL, Lenzi A \& Foresta C 2006a Changes in serum insulin-like factor 3 during normal male puberty. Journal of Clinical Endocrinology and Metabolism 91 3426-3431. (doi:10.1210/ jc.2006-0821)

Ferlin A, Bogatcheva NV, Gianesello L, Pepe A, Vinanzi C, Agoulnik AI \& Foresta C $2006 \mathrm{~b}$ Insulin-like factor 3 gene mutations in testicular dysgenesis syndrome: clinical and functional characterization. Molecular Human Reproduction 12 401-406. (doi:10.1093/molehr/gal043)

Foresta C \& Ferlin A 2004 Role of INSL3 and LGR8 in cryptorchidism and testicular functions. Reproductive Biomedicine Online 9 294-298. (doi:10.1016/S1472-6483(10)62144-X)

Foresta C, Bettella A, Vinanzi C, Dabrilli P, Meriggiola MC, Garolla A \& Ferlin A 2004 A novel circulating hormone of testis origin in humans. Journal of Clinical Endocrinology and Metabolism 89 5952-5958. (doi:10.1210/jc.2004-0575)

Hagen CP, Aksglaede L, Sorensen K, Mouritsen A, Andersson AM, Petersen JH, Main KM \& Juul A 2012 Individual serum levels of anti-Mullerian hormone in healthy girls persist through childhood and adolescence: a longitudinal cohort study. Human Reproduction $\mathbf{2 7}$ 861-866. (doi:10.1093/humrep/der435)

Heng K, Ivell R, Wagaarachchi P \& Anand-Ivell R 2008 Relaxin signalling in primary cultures of human myometrial cells. Molecular Human Reproduction 14 603-611. (doi:10.1093/molehr/gan051)

Hsu SY, Nakabayashi K, Nishi S, Kumagai J, Kudo M, Sherwood OD \& Hsueh AJ 2002 Activation of orphan receptors by the hormone relaxin. Science 295 671-674. (doi:10.1126/science.1065654)

Huang Z, Rivas B \& Agoulnik AI 2012 Insulin-like 3 signaling is important for testicular descent but dispensable for spermatogenesis and germ cell survival in adult mice. Biology of Reproduction 87 143. (doi:10.1095/ biolreprod.112.103382)

Hutson JM 2013 Undescended testis: the underlying mechanisms and the effects on germ cells that cause infertility and cancer. Journal of Pediatric Surgery 48 903-908. (doi:10.1016/j.jpedsurg.2013.02.001)

Ivell R \& Anand-Ivell R 2009 Biology of insulin-like factor 3 in human reproduction. Human Reproduction Update 15 463-476. (doi:10.1093/ humupd/dmp011)

Ivell R, Wade JD \& Anand-Ivell R 2013 INSL3, as a biomarker of Leydig cell functionality. Biology of Reproduction 88 147. (doi:10.1095/biolreprod. 113.108969)

Karaman MI, Kaya C, Caskurlu T, Guney S \& Ergenekon E 2005 Measurement of pediatric testicular volume with Prader orchidometer: comparison of different hands. Pediatric Surgery International 21 517-520. (doi:10.1007/s00383-005-1470-1)

Kawamura K, Kumagai J, Sudo S, Chun SY, Pisarska M, Morita H, Toppari J, Fu P, Wade JD, Bathgate RA et al. 2004 Paracrine regulation of mammalian oocyte maturation and male germ cell survival. PNAS 101 7323-7328. (doi:10.1073/pnas.0307061101)

Koenis MM, Brouwer RM, van Baal GC, van Soelen IL, Peper JS, van Leeuwen $M$, Delemarre-van de Waal HA, Boomsma DI \& Hulshoff Pol HE 2013 Longitudinal study of hormonal and physical development in young twins. Journal of Clinical Endocrinology and Metabolism 98 E518-E527. (doi:10.1210/jc.2012-3361)

Kubota Y, Temelcos C, Bathgate RA, Smith KJ, Scott D, Zhao C \& Hutson JM 2002 The role of insulin 3, testosterone, Mullerian inhibiting substance and relaxin in rat gubernacular growth. Molecular Human Reproduction 8 900-905. (doi:10.1093/molehr/8.10.900) 
Kumagai J, Hsu SY, Matsumi H, Roh JS, Fu P, Wade JD, Bathgate RA \& Hsueh AJ 2002 INSL3/Leydig, insulin-like peptide activates the LGR8 receptor important in testis descent. Journal of Biological Chemistry 277 31283-31286. (doi:10.1074/jbc.C200398200)

Lin CC, Huang WJ \& Chen KK 2009 Measurement of testicular volume in smaller testes: how accurate is the conventional orchidometer? Journal of Andrology 30 685-689. (doi:10.2164/jandrol.108.006460)

Mouritsen A, Aksglaede L, Soerensen K, Hagen CP, Petersen $\mathrm{JH}$, Main KM \& Juul A 2013 The pubertal transition in 179 healthy Danish children: associations between pubarche, adrenarche, gonadarche, and body composition. European Journal of Endocrinology 168 129-136. (doi:10.1530/EJE-12-0191)

Mouritsen A, Søeborg T, HolmJohannsen T, Aksglaede L, Soerensen K, Hagen CP, Mieritz M, Frederiksen H, Andersson AM \& Juul A 2014 Longitudinal changes in circulating testosterone levels determined by LCMS/MS and by a commercially available radioimmunoassay in healthy girls and boys during the pubertal transition. Hormone Research in Paediatrics.

Nef S \& Parada LF 1999 Cryptorchidism in mice mutant for Insl3. Nature Genetics 22 295-299. (doi:10.1038/10364)

Prader A 1966 Testicular size: assessment and clinical importance. Triangle 7 240-243.

Resko JA \& Eik-nes KB 1966 Diurnal testosterone levels in peripheral plasma of human male subjects. Journal of Clinical Endocrinology and Metabolism 26 573-576. (doi:10.1210/jcem-26-5-573)

Rivkees SA, Hall DA, Boepple PA \& Crawford JD 1987 Accuracy and reproducibility of clinical measures of testicular volume. Journal of Pediatrics 110 914-917. (doi:10.1016/S0022-3476(87)80412-2)

Roth MY, Lin K, Bay K, Amory JK, Anawalt BD, Matsumoto AM, Marck BT, Bremner WJ \& Page ST 2013 Serum insulin-like factor 3 is highly correlated with intratesticular testosterone in normal men with acute, experimental gonadotropin deficiency stimulated with low-dose human chorionic gonadotropin: a randomized, controlled trial. Fertility and Sterility 99 132-139. (doi:10.1016/j.fertnstert.2012.09.009)

Sadeghian H, Anand-Ivell R, Balvers M, Relan V \& Ivell R 2005 Constitutive regulation of the Insl3 gene in rat Leydig cells. Molecular and Cellular Endocrinology 241 10-20. (doi:10.1016/j.mce.2005.03.017)

Sakamoto H, Saito K, Oohta M, Inoue K, Ogawa Y \& Yoshida H 2007 Testicular volume measurement: comparison of ultrasonography, orchidometry, and water displacement. Urology 69 152-157. (doi:10.1016/ j.urology.2006.09.012)

Soeborg $T$, Frederiksen $H$, Fruekilde $P$, Johannsen $T H$, Juul A \& Andersson AM 2013 Serum concentrations of DHEA, DHEAS,
$17 \alpha$-hydroxyprogesterone, $\Delta 4$-androstenedione and testosterone in children determined by TurboFlow-LC-MS/MS. Clinica Chimica Acta 419 95-101. (doi:10.1016/j.cca.2013.01.019)

Sorensen K, Aksglaede L, Petersen JH \& Juul A 2010 Recent changes in pubertal timing in healthy Danish boys: associations with body mass index. Journal of Clinical Endocrinology and Metabolism 95 263-270. (doi:10.1210/jc.2009-1478)

Tatsunami S, Matsumiya K, Tsujimura A, Itoh N, Sasao T, Koh E, Maeda Y, Eguchi J, Takehara K, Nishida T et al. 2006 Inter/intra investigator variation in orchidometric measurements of testicular volume by ten investigators from five institutions. Asian Journal of Andrology 8 373-378. (doi:10.1111/j.1745-7262.2006.00143.x)

Tomboc M, Lee PA, Mitwally MF, Schneck FX, Bellinger M \& Witchel SF 2000 Insulin-like 3/relaxin-like factor gene mutations are associated with cryptorchidism. Journal of Clinical Endocrinology and Metabolism 85 4013-4018. (doi:10.1210/jcem.85.11.6935)

Veldhuis JD, King JC, Urban RJ, Rogol AD, Evans WS, Kolp LA \& Johnson ML 1987 Operating characteristics of the male hypothalamopituitary-gonadal axis: pulsatile release of testosterone and folliclestimulating hormone and their temporal coupling with luteinizing hormone. Journal of Clinical Endocrinology and Metabolism 65 929-941. (doi:10.1210/jcem-65-5-929)

Wikstrom AM, Bay K, Hero M, Andersson AM \& Dunkel L 2006 Serum insulin-like factor 3 levels during puberty in healthy boys and boys with Klinefelter syndrome. Journal of Clinical Endocrinology and Metabolism 91 4705-4708. (doi:10.1210/jc.2006-0669)

Wu FC, Brown DC, Butler GE, Stirling HF \& Kelnar CJ 1993 Early morning plasma testosterone is an accurate predictor of imminent pubertal development in prepubertal boys. Journal of Clinical Endocrinology and Metabolism 76 26-31. (doi:10.1210/jcem.76.1.8421096)

Zimmermann S, Steding G, Emmen JM, Brinkmann AO, Nayernia K, Holstein AF, Engel W \& Adham IM 1999 Targeted disruption of the Insl3 gene causes bilateral cryptorchidism. Molecular Endocrinology 13 681-691. (doi:10.1210/mend.13.5.0272)

Received 9 September 2013

First decision 5 November 2013

Revised manuscript received 16 January 2014

Accepted 22 January 2014 